\title{
Results of Surgery in Hypertension Due to Renal Artery Stenosis
}

\author{
R. G. LUKE,* M.B., M.R.C.P., M.R.C.P.ED. ; A. C. KENNEDY, † M.D., F.R.C.P.ED., F.R.C.P.GLASG. \\ J. D. BRIGGS, $\ddagger$ M.B., M.R.C.P., M.R.C.P.ED., M.R.C.P.GLASG. ; N. W. STRUTHERS, $\$$ CH.M., F.R.C.S., F.R.C.S.ED. \\ J. K. WATT, $\|$ CH.M., B.SC., F.R.C.S., F.R.C.S.GLASG. ; D. W. SHORT, G CH.M., B.SC., F.R.C.S.ED., F.R.C.S.GLASG. \\ W. BARR STIRLING,** CH.M., F.R.C.S.ED., F.R.C.S.GLASG.
}

\author{
Bnit. med.9., 1968, 2, 76-80
}

We have previously reported our experience on the detection If renovascular hypertension, a combination of intravenous गyelography and isotope renography being used as a screening procedure in hypertensive patients (Kennedy et al., 1965 ; Luke et al., 1966). In this paper we give an account of the effect of surgical treatment in the 27 patients with renal artery stenosis sperated on up to May 1966, so that the minimum follow-up period was at least one year. These 27 patients originated from a group of 41 with functional renal artery stenosis found by screening about 1,000 patients with hypertension. We shall report separately the results of surgery in the slightly greater number of patients with unilateral chronic pyelonephritis and other forms of unilateral parenchymal renal disease originating from the same group of hypertensive patients.

\section{Patients}

Preoperative clinical details, results of renovascular investigations, and the operative procedures carried out are shown in Table I.

There were 17 males and 10 females, with a mean age of +0.5 years (range 19 to 61 ). Mean preoperative diastolic blood pressure was $123 \mathrm{~mm} . / \mathrm{Hg}$. With the system of grading of fundi proposed by Keith et al. (1939) three patients had grade 4 fundi, eight grade 3,11 grade 2 , four grade 1 , while in one patient (Case 10) there were no hypertensive fundal changes. In eight patients a significant abdominal bruit was heard. In 19 of the 27 patients the E.C.G. showed a left ventricular strain pattern. The mean duration of relevant symptoms or the period of elevation of blood pressure where known was 13 months (range 2 months to 12 years). One patient (Case 14) was asymptomatic, the hypertension being detected at a routine medical examination. Six of the eight female patients who had had at least one pregnancy gave a history of hypertension persisting after toxaemia of pregnancy.

In 18 of the patients there was no proteinuria. Mean preoperative blood urea was $33 \mathrm{mg} . / 100 \mathrm{ml}$.s the highest value being $55 \mathrm{mg}$., and the mean preoperative creatinine clearance was $95 \mathrm{ml}$./minute, the lowest value being $47 \mathrm{ml}$. In all 27 patients bacteriological examination of a midstream specimen of urine was negative.

Seventeen patients (14 males and three females) had atherosclerotic lesions, eight (five females and three males) had fibromuscular dysplasia (Harrison et al., 1967) of the renal arteries, one (Case 4) had Takayasu's arteritis (Short et al., 1965), and

\footnotetext{
- Lecturer in Medicine, University Department of Medicine, Royal Infirmary, Glasgow C.4.

t Reader in Medicine, University Department of Medicine, Royal Infirmary, Glasgow C.4.

¥ Registrar in Medicine, University Department of Medicine, Royal Infirmary, Glasgow C.4.

5 Consultant Urological Surgeon, Department of Urology, Royal Infirmary, Glasgow C.4.

|| Consultant Surgeon, Royal Infirmary, Glasgow C.4.

Senior Lecturer, University Department of Surgery, Royal Infirmary, Glasgow C.4.

* Consultant Urologist, Department of Urology, Royal Infirmary, Glasgow C.4.
}

one (Case 17) had congenital narrowing of the abdominal aorta with involvement of both renal arteries. The mean age of the patients with fibromuscular dysplasia was 31 years and that of the patients with atherosclerotic lesions 46 years.

\section{Basis of Diagnosis of Renovascular Hypertension}

In accordance with our previously described diagnostic polic (Kennedy et al., 1965 ; Luke et al., 1966) all of the patients had been selected as likely to have a functionally active renal artery stenosis as a result of screening with a "hypertensive" intravenous pyelogram (I.V.P.) and an isotope renogram. In 26 of the 27 patients the I.V.P. showed one or more changes associated with renal artery stenosis, the negative result being obtained in Case 2. The renogram was also positive in 26 of the 27 cases; the negative result was obtained in a differen patient (Case 17) who had bilateral renal artery stenosis associated with congenital narrowing of the abdominal aorta. In 13 patients a $C$ type of renogram curve was obtained, in nine a B type, and in four an A type (Luke et al., 1966). Aortograms confirmed the presence of stenosis in all 27 patients. In 19 patients technically satisfactory divided renal function tests were obtained, and in 18 of these the result was positive (Kennedy et al., 1965). In six patients (Cases 1, 8, 12, 20, 21, and 24) antihypertensive drug therapy before operation had failed to control the blood pressure satisfactorily.

\section{Type of Operation}

Elective nephrectomy was carried out in 12 patients and reconstructive vascular surgery in 10 (Table 1 ). In two patients secondary nephrectomy was carried out-in one (Case 27) three weeks after the first operation because of graft thrombosis, and in the other (Case 12) two years after it and three months after the routine follow-up admission because of renal vein thrombosis on the operated side. In the remaining five patients a reconstructive procedure was planned, but at operation nephrectomy had to be carried out for technical reasons, including involvement of the division of the renal artery by fibromuscular dysplasia in two (Cases 2 and 14). In 14 patients the systolic transstenotic pressure gradient was measured; it ranged from 20 to $200 \mathrm{~mm}$./ $\mathrm{Hg}$, with a mean of $85 \mathrm{~mm}$./ Hg. The mean weight of the kidney in the 19 patients in whom nephrectomy was performed was $116 \mathrm{~g}$. In 15 of these kidneys ischaemic tubular atrophy of varying degrees of severity was seen. In four patients, in all of whom reconstructive vasculas surgery had been unsuccessfully attempted, the removed kidney showed no significant histological change.

\section{Results}

Results were assessed on the basis of regular outpatien attendances supplemented by a short admission to. hospital at least one year after operation in order to obtain serial blood- 
TABle I.-Preoperative Data and Type of Surgery Performed in 27 Patients with Renal Artery Stenosw

\begin{tabular}{|c|c|c|c|c|c|c|c|c|c|c|c|c|c|c|c|c|c|}
\hline $\begin{array}{l}\text { Case } \\
\text { No. }\end{array}$ & $\begin{array}{l}\text { Age } \\
\text { and } \\
\text { Sex }\end{array}$ & $\begin{array}{l}\text { B.P. } \\
\text { (mm. } \\
\text { Hg) }\end{array}$ & $\begin{array}{l}\text { Length } \\
\text { of } \\
\text { History } \\
\text { (mths.) }\end{array}$ & $\begin{array}{c}\text { Fundi } \\
\text { (grade) }\end{array}$ & Bruit & C.G. & $\begin{array}{c}\text { Blood } \\
\text { Urea } \\
\text { (mg. } \\
100 \mathrm{ml} .) \\
\end{array}$ & $\begin{array}{l}\text { Creatinine } \\
\text { Clearance } \\
\text { (ml./min.) }\end{array}$ & $\begin{array}{l}\text { Plasma } \\
\text { Sodium } \\
(\mathrm{mEq} / \mathrm{l} .)\end{array}$ & $\begin{array}{l}\text { Jrine } \\
\text { cotein }\end{array}$ & I.V.P. & eno: & $\begin{array}{l}\text { Divided } \\
\text { Renal } \\
\text { Function } \\
\text { Tests } \\
\end{array}$ & $\begin{array}{l}\text { Gra- } \\
\text { dient } \\
(\mathrm{mm} . \\
\mathrm{Hg} .)\end{array}$ & $\begin{array}{c}\text { Weight } \\
\text { of } \\
\text { Kidney } \\
\text { (g.) }\end{array}$ & $\begin{array}{c}\text { Cause } \\
\text { of Sten- } \\
\text { osist }\end{array}$ & Operation \\
\hline $\begin{array}{l}1 \\
2 \\
3\end{array}$ & $\begin{array}{ll}56 & \mathrm{M} \\
26 & \mathrm{~F} \\
39 & \mathrm{M}\end{array}$ & \begin{tabular}{|l|}
$230 / 115$ \\
$170 / 120$ \\
$180 / 130$
\end{tabular} & $\begin{array}{r}4 \\
36 \\
3\end{array}$ & $\begin{array}{l}3 \\
2 \\
3\end{array}$ & $\bar{z}$ & $\begin{array}{l}\text { V.S. } \\
\text { Veative } \\
\text { v.s. }\end{array}$ & $\begin{array}{l}20 \\
28\end{array}$ & $\begin{array}{r}90 \\
114 \\
118\end{array}$ & $\begin{array}{l}136 \\
133 \\
138\end{array}$ & $\begin{array}{c}\text { Trace } \\
-\end{array}$ & \pm & $\begin{array}{l}\stackrel{C}{C} \\
\text { C }\end{array}$ & $\frac{ \pm}{+}$ & $\begin{array}{l}\text { N.D. } \\
200\end{array}$ & $\begin{array}{l}125 \\
120\end{array}$ & $\begin{array}{l}\text { Ath. } \\
\text { F.D. } \\
\text { Ath. }\end{array}$ & $\begin{array}{l}\text { Nephrectomy } \\
\text { Teflon" bypan }\end{array}$ \\
\hline 4 & $36 \mathrm{~F}$ & $240 / 120$ & 6 & 1 & + & $"$ & 20 & 103 & 139 & - & + & C & + & N.D. & - & $T$ & \\
\hline $\begin{array}{l}5 \\
6 \\
7 \\
8 \\
9\end{array}$ & $\begin{array}{ll}49 & \mathrm{~F} \\
44 & \mathrm{P} \\
56 & \mathrm{M} \\
44 & \mathrm{M} \\
50 & \mathrm{M}\end{array}$ & $\mid$\begin{tabular}{l|}
$280 / 130$ \\
$195 / 115$ \\
$200 / 120$ \\
$210 / 125$ \\
$200 / 100$
\end{tabular} & $\begin{array}{r}36 \\
6 \\
2 \\
6 \\
2\end{array}$ & $\begin{array}{l}2 \\
2 \\
4 \\
1 \\
2\end{array}$ & $\begin{array}{l} \pm \\
\pm \\
=\end{array}$ & $\begin{array}{l}\text { ", } \\
\text { Negative } \\
\text { Isch. } \\
\text { L.V.s. }\end{array}$ & $\begin{array}{l}40 \\
34 \\
24 \\
48 \\
45\end{array}$ & $\begin{array}{l}\overline{67} \\
86 \\
82 \\
47\end{array}$ & $\begin{array}{l}140 \\
140 \\
141 \\
138 \\
136\end{array}$ & $\begin{array}{c}\overline{-} \\
\text { Trace } \\
\overline{-} \\
1.8 \mathrm{~g} .\end{array}$ & $\begin{array}{l} \pm \\
\pm \\
+ \\
+\end{array}$ & $\begin{array}{l}\text { B } \\
\text { C } \\
\text { C } \\
\text { B } \\
\text { B }\end{array}$ & $\begin{array}{l}+ \\
+ \\
+ \\
+ \\
+\end{array}$ & $\begin{array}{l}120 \\
\text { N.D. } \\
130 \\
\text { N.D. } \\
\text { ” }\end{array}$ & $\begin{array}{l}140 \\
130 \\
110 \\
150 \\
120\end{array}$ & $\begin{array}{l}\text { Ath. } \\
\text { F.D. } \\
\text { Ath. } \\
\text { ". }\end{array}$ & $\begin{array}{c}\text { Nephrectomy } \\
\# " \\
\#\end{array}$ \\
\hline $\begin{array}{l}10 \\
11 \\
12\end{array}$ & $\begin{array}{l}19 \mathrm{M} \\
42 \\
49 \\
49\end{array}$ & $\begin{array}{l}155 / 110 \\
190 / 125 \\
210 / 140\end{array}$ & $\begin{array}{l}3 \\
6 \\
9\end{array}$ & $\begin{array}{l}0 \\
2 \\
3\end{array}$ & $\bar{z}$ & $\begin{array}{l}\text { Isch. } \\
\text { L.V.s. }\end{array}$ & $\begin{array}{l}30 \\
36 \\
42\end{array}$ & $\begin{array}{l}116 \\
125 \\
71\end{array}$ & $\begin{array}{l}137 \\
141 \\
135\end{array}$ & & $\begin{array}{l}+ \\
+ \\
+\end{array}$ & $\begin{array}{l}\text { C } \\
\text { B }\end{array}$ & $\begin{array}{l}+ \\
+ \\
+\end{array}$ & $\begin{array}{l}20 \\
50 \\
20\end{array}$ & $\begin{array}{l}125 \\
120 \\
-\end{array}$ & $\begin{array}{l}\text { F.D. } \\
\text { Ath. } \\
\text { " }\end{array}$ & pleno-renal \\
\hline $\begin{array}{l}13 \\
14 \\
15\end{array}$ & $\begin{array}{ll}38 & \mathrm{M} \\
32 & \mathrm{~F} \\
31 & \mathrm{M}\end{array}$ & \begin{tabular}{|l|}
$180 / 120$ \\
$200 / 115$ \\
$230 / 140$
\end{tabular} & $\frac{9}{4}$ & $\begin{array}{l}3 \\
2 \\
4\end{array}$ & $\bar{t}$ & $"$ & $\begin{array}{l}32 \\
30 \\
27\end{array}$ & $\overline{77}$ & $\begin{array}{l}140 \\
132 \\
134\end{array}$ & Trace & $\begin{array}{l}+ \\
+ \\
+\end{array}$ & $\begin{array}{l}\mathbf{A} \\
\mathbf{C}\end{array}$ & $\begin{array}{r}+ \\
+ \\
\text { N.D. }\end{array}$ & $\begin{array}{l}20 \\
140 \\
\text { N.D. }\end{array}$ & $\begin{array}{r}77 \\
110 \\
130\end{array}$ & $\begin{array}{l}\text { F.D. } \\
\text { Ath. }\end{array}$ & $\begin{array}{c}\text { Nephrecton } \\
\# "\end{array}$ \\
\hline $\begin{array}{l}16 \\
17\end{array}$ & & 120 & $\begin{array}{r}8 \\
24\end{array}$ & $\begin{array}{l}2 \\
2\end{array}$ & $\bar{t}$ & $"$ & $\begin{array}{l}38 \\
24\end{array}$ & $\begin{array}{l}93 \\
71\end{array}$ & 14 & & $\begin{array}{l}+ \\
+\end{array}$ & $A$ & " & $\begin{array}{c}37 \\
\text { (bila- } \\
\text { teral) }\end{array}$ & & $\begin{array}{l}\text { Con.+ } \\
\text { Ath. }\end{array}$ & $\begin{array}{c}\text { Bifurcäe Dac } \\
\text { ron bypass } \\
\text { graft }\end{array}$ \\
\hline 18 & $56 \mathrm{M}$ & $0 / 110$ & 3 & 3 & - & " & 36 & 136 & 139 & - & + & B & " & 120 & 120 & Ath. & on bypass \\
\hline $\begin{array}{l}19 \\
20\end{array}$ & $\begin{array}{ll}51 & \mathrm{M} \\
40 & \mathrm{~F}\end{array}$ & $0 / 115$ & $\begin{array}{l}24 \\
20\end{array}$ & $\begin{array}{l}3 \\
3\end{array}$ & $\mp$ & $"$ & $\begin{array}{l}31 \\
23\end{array}$ & $\overline{94}$ & $\begin{array}{l}135 \\
138\end{array}$ & . & + & $\begin{array}{l}\text { C } \\
\text { B }\end{array}$ & $"$ & $\begin{array}{l}90 \\
\text { N.D. }\end{array}$ & $\begin{array}{r}180 \\
68\end{array}$ & " & $\begin{array}{c}\text { Nephrectomy } \\
"\end{array}$ \\
\hline $\begin{array}{l}21 \\
22\end{array}$ & $\begin{array}{l}36 \mathrm{M} \\
42 \mathrm{P}\end{array}$ & $\mid$\begin{tabular}{|l|}
$200 / 125$ \\
$240 / 130$
\end{tabular} & $\begin{array}{r}6 \\
18\end{array}$ & $\frac{1}{4}$ & $\stackrel{+}{+}$ & $\begin{array}{l}\text { Negative } \\
\text { L.V.S. }\end{array}$ & $\begin{array}{l}40 \\
55\end{array}$ & $\begin{array}{r}116 \\
69\end{array}$ & $\begin{array}{l}141 \\
138\end{array}$ & & + & $\begin{array}{l}\mathrm{C} \\
\mathrm{A}\end{array}$ & N. $\stackrel{+}{D}$. & $"$ & 60 & $\begin{array}{l}\text { F.D. } \\
\text { Ath. }\end{array}$ & $\begin{array}{l}\text { Reimplantation } \\
\text { Nephrectomy }\end{array}$ \\
\hline 23 & $43 \mathrm{M}$ & $180 / 110$ & 6 & 2 & - & Negative & 34 & 89 & 141 & & + & B & + & 60 & - & " & $\begin{array}{l}\text { Thrombo- } \\
\text { endarterec- } \\
\text { tomy + vein } \\
\text { patch }\end{array}$ \\
\hline $\begin{array}{l}24 \\
25 \\
26\end{array}$ & $\left|\begin{array}{ll}41 & M \\
38 & F \\
20 & M\end{array}\right|$ & $\begin{array}{l}250 / 150 \\
200 / 125 \\
200 / 120\end{array}$ & $\begin{array}{r}2 \\
144 \\
12\end{array}$ & $\begin{array}{l}2 \\
2 \\
1\end{array}$ & \pm & $\begin{array}{l}\text { L.V.S. } \\
\text { Negative }\end{array}$ & $\begin{array}{l}33 \\
15 \\
26\end{array}$ & $\begin{array}{l}103 \\
93 \\
134\end{array}$ & $\begin{array}{l}140 \\
141 \\
136\end{array}$ & Trace & \pm & $\begin{array}{l}\text { C } \\
\text { B }\end{array}$ & $\begin{array}{c}\text { N.D. } \\
+ \\
+\end{array}$ & $\begin{array}{l}80 \\
\text { N.D. } \\
\text { " }\end{array}$ & 110 & F.D. & $\begin{array}{l}\text { Reimplantation } \\
\text { Nephrectomy } \\
\text { Teflon bypass }\end{array}$ \\
\hline 27 & $34 \mathrm{~F}$ & $190 / 130$ & 30 & 3 & - & L.v.S. & 33 & 93 & 139 & + & + & B & + & 100 & 130 & " & \\
\hline
\end{tabular}

L.V.S. $=$ Left ventricular strain. Isch. $=$ Myocardial ischaemia. N.D. $=$ Not done. $* A=$ Flat curve. $B=$ Flattening of phase 2 and delay of phase 3 . C $=$ Delay of phase 3 . t Ath. $=$ Atherosclerosis. F.D. $=$ Fibromuscular dysplasia. Tak. art. $=$ Takayasu's arteritis. Con. $=$ Congenital narrowing of aorta.

pressure readings, fundoscopic assessment, chest $x$-ray picture, E.C.G., blood urea and electrolytes, chemical, microscopical, and bacteriological examination of urine, endogenous creatinine clearance, I.V.P., and isotope renogram. This short admission was possible in all the patients surviving for at least one year after operation except in two (Cases 26 and 27), who now reside in England. In Case 27 a reasonably satisfactory assessment was obtained by postal inquiry from her medical attendants.

TABle II.-Postoperative Data and Results of Surgery in 27 Patients with Renal Artery Stenosis

\begin{tabular}{|c|c|c|c|c|c|c|c|c|c|}
\hline $\begin{array}{l}\dot{0} \\
z \\
8 \\
8\end{array}$ & 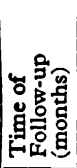 & $\underset{(\mathbf{m m} \cdot \mathbf{H} \mathbf{g})}{\text { B.P. }}$ & 泀兽 & E.C.G. & 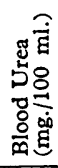 & 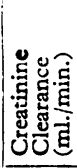 & 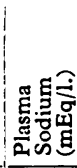 & 竞 & Result \\
\hline 1 & 47 & $190 / 95$ & 1 & L.V.S. & 38 & 80 & 137 & - & Improved \\
\hline 2 & 44 & $140 / 80$ & 1 & $=$ & 28 & 102 & 142 & $=$ & Corrected \\
\hline 4 & $\begin{array}{l}42 \\
40\end{array}$ & $160 / 100$ & 1 & $=$ & 23 & 80 & 140 & 二 & Improved \\
\hline 5 & 33 & $190 / 90 \dagger$ & 2 & $\overline{\mathrm{c}}$ & 36 & 57 & 143 & $=$ & Failed \\
\hline $\begin{array}{l}6 \\
7\end{array}$ & $\begin{array}{l}32 \\
26\end{array}$ & $\begin{array}{l}130 / 85 \\
190 / 90\end{array}$ & $\begin{array}{l}1 \\
0\end{array}$ & L.V.S. (1) & $\begin{array}{l}36 \\
35\end{array}$ & $\begin{array}{l}67 \\
64\end{array}$ & $\begin{array}{l}142 \\
144\end{array}$ & $=$ & Corrected \\
\hline $\begin{array}{l}8 \\
9\end{array}$ & 30 & $150 / 100$ & 1 & Isch. & $\begin{array}{l}50 \\
25\end{array}$ & $\begin{array}{l}65 \\
\text { N. }\end{array}$ & $\begin{array}{l}139 \\
138\end{array}$ & 二 & Improved \\
\hline 10 & 25 & $115 / 80$ & 0 & & 32 & 82 & 142 & - & "or \\
\hline 11 & 24 & $120 / 70$ & 2 & Isch. & 32 & N.D. & & - & " \\
\hline 12 & 21 & $140 / 90$ & 1 & $"$ & $\begin{array}{l}32 \\
34\end{array}$ & $\begin{array}{l}67 \\
65\end{array}$ & 141 & $0.3 \mathrm{~g}$. & $"$ \\
\hline 14 & 19 & $140 / 90$ & 0 & 一 & 34 & 55 & 141 & - & ", \\
\hline $\begin{array}{l}15 \\
16\end{array}$ & $\begin{array}{l}18 \\
15\end{array}$ & $\begin{array}{l}140 / 90 \\
140 / 95\end{array}$ & $\begin{array}{l}0 \\
1\end{array}$ & L.V.S. & $\begin{array}{l}29 \\
40\end{array}$ & $\begin{array}{l}78 \\
56\end{array}$ & $\begin{array}{l}140 \\
140\end{array}$ & $0 . \overline{5} \mathrm{~g}$. & Improved \\
\hline 17 & $\begin{array}{c}4 \\
\text { (died) }\end{array}$ & $120 / 80$ & & N.D. & 25 & N.D. & & & \\
\hline$\therefore 3$ & Died & - & - & 川 & - & " & - & - & - \\
\hline 19 & $\begin{array}{c}6 \\
\text { (died) }\end{array}$ & $130 / 80$ & - & $"$ & 35 & $\therefore$ &  & 一 & - \\
\hline $\begin{array}{l}20 \\
21\end{array}$ & $\begin{array}{l}16 \\
12\end{array}$ & $\begin{array}{l}150 / 95 \\
140 / 80\end{array}$ & 1 & L.V.S. (1) & $\begin{array}{l}28 \\
43\end{array}$ & 95 & $\begin{array}{l}141 \\
138\end{array}$ & $=$ & $\begin{array}{l}\text { Improved } \\
\text { Corrected }\end{array}$ \\
\hline $\begin{array}{l}22 \\
23\end{array}$ & 14 & $\begin{array}{l}120 / 80 \\
140 / 90\end{array}$ & $\begin{array}{l}2 \\
1\end{array}$ & $\bar{z}$ & $\begin{array}{l}56 \\
38\end{array}$ & $\begin{array}{r}36 \\
104\end{array}$ & $\begin{array}{l}141 \\
143\end{array}$ & $=$ & , \\
\hline 24 & & $170 / 105$ & 2 & - & 30 & 92 & 143 & - & Improved \\
\hline 2 & & $160 / 100$ & I & N.D. & 30 & N.D. & - & N.D. & Improved \\
\hline & & 30 & & ״ & & 956 & - & & rected \\
\hline
\end{tabular}

N.D. $=$ Not done.
L.V.S. (1) $=$ Left ventricular strain (improved, as compared with preoperative tOn methyldopa.

Estimations 18 months after operation.
The condition of the other patient when last seen by us nine months postoperatively is used in the assessment; he is known to have been alive until March 1967, but details of his blood pressure are not available.

Follow-up data are shown in Table II. The duration of follow-up was taken as the time interval between operation and the short admission study period, and ranged from 12 to 47 months, with a mean of 25 months. In assessing the effects of renovascular surgery on the blood pressure three terms are employed: (1) correction-diastolic blood pressure of $90 \mathrm{~mm}$. $\mathrm{Hg}$ or less ; (2) improvement-fall in diastolic blood pressure of $20 \mathrm{~mm}$. or more without hypotensive therapy; and (3) failures-others. We have avoided the word "cure," since, especially with an atherosclerotic lesion, correction of the hypertension may do no more than slow the rate of progression of the underlying diffuse atherosclerotic disease process.

The results of surgery in the 27 operated cases are summarized in Table III. There was one operative death due to thrombosis in an extremely atherosclerotic aorta 48 hours after an attempt at reconstructive vascular surgery (Case 18). One patient (Case 17) with extensive congenital narrowing of the aorta died of haemorrhage from the junction of a bilateral bypass graft four months after surgery, and another (Case 19) died of haemorrhage six months after reconstructive surgery which had been complicated by subphrenic abscess. In both instances outpatient supervision showed that the blood pressure had been corrected (B.P. 120/80 and 130/80 respectively) in the period between surgery and death. In 23 of the remaining 24 patients blood pressure was corrected or improved. In the seven patients in whom the blood pressure was improved the mean fall in diastolic was $27 \mathrm{~mm}$. $\mathrm{Hg}$, with a range of $20-45 \mathrm{~mm}$. Hg. Two other patients have died since the short admission study for reasons unrelated to their previous nephrectomy-one (Case 11) died after a myocardial infarction 28 months after surgery, and another (Case 14) died from anaplastic bronchial carcinoma 23 months after surgery. In both patients hypertension had been corrected.

Three vascular incidents related to extrarenal atherosclerosis have occurred. In Case 8 a left hemiparesis developed, sub- 
sequently followed by a myocardial infarction; however, the patient made a fair recovery and was working again. Bloodpressure levels were unaltered. In one patient (Case 5), in vhom there was no response to nephrectomy, symptoms of peripheral vascular disease developed. In all the other patients assessment remained, at the time of writing, as at the admission period except for one (Case 12), in whom renal vein thrombosis on the operated side led to redevelopment of hypertension; thereafter nephrectomy improved the blood pressure. In summary the blood pressure was initially corrected or improved in $93 \%$ of patients, but because of the two late "operative" leaths the final figure for correction or improvement of blood pressure is $85 \%$.

TABLB III.-Summary of Results of Surgery

\begin{tabular}{|c|c|c|c|c|c|c|}
\hline & & & & & No. of Cases & Percentage \\
\hline $\begin{array}{l}\text { 8.P. correcte } \\
\text { B.P. improve } \\
\text { No efiect on } \\
\text { Immedinte o } \\
\text { Late opernt }\end{array}$ & $\begin{array}{l}\because \ddot{0} \\
\text { erpative death } \\
\text { deaths }\end{array}$ & $\begin{array}{l}\because \\
\because \\
\therefore\end{array}$ & $\begin{array}{l}\ddot{0} \\
\ddot{0} \\
\ddot{0}\end{array}$ & $\begin{array}{l}\because . \\
\ddot{0} \\
\ddot{0}\end{array}$ & $\begin{array}{r}16 \\
7 \\
1 \\
1 \\
2\end{array}$ & $\begin{array}{c}59.2 \dagger \\
25.9 \\
3.7 \\
3.7 \\
7.4 \\
\end{array}$ \\
\hline Total & .. & .. & .. & .. & 27 & 99.9 \\
\hline
\end{tabular}

- Cases 17 and 19. These patients died four und six months respectively after murgery, the B.P. having been corrected in the interim period.

Includes two patients who subsequently died: Case 14 from bronchial carcinom 23 months after surgery; Case 11 from myocardial infarction 28 months after surgery.

Because of the relation between plasma renin and serum sodium levels (Brown et al., 1965) and the possible relation between renovascular hypertension and the renin-angiotensin system, the preoperative and follow-up admission plasma sodium levels were compared. There was a significant rise in plasma sodium levels after operation (Table IV).

TABLB IV.-Renal Function, Plasma Sodium, and P.C.V. Before and After Renovascular Surgery

\begin{tabular}{|c|c|c|c|c|c|}
\hline & & Before* & Aftert & $n \neq$ & t Test5 \\
\hline 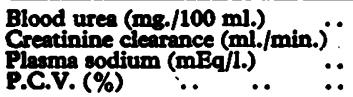 & $\ddot{\prime}$ & $\begin{array}{r}32 \cdot 7 \\
94.7 \\
138.2 \\
43 \cdot 0\end{array}$ & $\begin{array}{r}33.8 \\
74.4 \\
140.9 \\
43.7\end{array}$ & $\begin{array}{l}25 \\
14 \\
21 \\
21\end{array}$ & $\begin{array}{l}\text { N.S. } \\
P<0.001 \\
P<0.001 \\
\text { N.S. }\end{array}$ \\
\hline
\end{tabular}

- Mean of all patients preoperatively.

t Mean of all patients at time of follow-up admission.

F Number of patients having estimations both before and after surgery.

Student's $t$ test on mean difference in this group ( $n$ ).

No significant alteration was observed in the mean blood urea levels before and after surgery, but there was a significant fall in creatinine clearance (Table IV). The mean postoperative creatinine clearance in all patients was $74.4 \mathrm{ml} . / \mathrm{min}$. For the patients who had nephrectomy the mean postoperative creatinine clearance was $69.4 \mathrm{ml} . / \mathrm{min}$.

Serial isotope renograms were carried out in patients who underwent reconstructive vascular surgery. In Cases 3, 4, 21, and 24 the renogram became normal, and in Case 12 it became normal until renal vein thrombosis occurred on the affected side 24 months after the initial operation. In Case 27 the renogram indicated no function 20 days after the original operation, when hypertension had increased to frankly malignant levels; at operation the graft was found thrombosed and nephrectomy was performed. In Case 26 there was a slight delay in the third phase of the curve-which had previously been a $B$ type-when the patient was last seen, associated with a still not normal B.P., which, especially in a young patient, suggests a degree of residual renal ischaemia. In those patients with normal renograms the I.V.P. had also become normal, while in Case 26 slight delay in excretion and increased density of the dye were still present.

\section{Discussion}

The British literature on the results of surgical treatment of renal artery stenosis is relatively sparse. Brown et al. (1960) gave a detailed account of the experience of the St. Mary's group with especial regard to the clinical features and diag. nosis ; and Owen (1967) reported 69 operated cases with : blood pressure correction rate of $43 \%$, a combined correction or improvement rate of $72 \%$, and six operative deaths. Thirtyone of these patients had nephrectomy, 22 being primary and 9 secondary procedures. Fenton et al. (1966) described the results of surgery in 15 patients with renal artery stenosis, 11 of whom had fibromuscular dysplasia ; blood pressure was corrected in eight and improved in two by nephrectomy. Other British workers reporting smaller series of cases have sounded a more pessimistic note (Chamberlain and Gleeson, 1965 ; Parsons et al., 1965 ; Groden et al., 1966).

The American literature is more extensive and more enthusiastic. De Bakey and his colleagues (Morris et al., 1966) reporn a series of 432 operated patients, $93 \%$ of whom had reconstructive vascular surgery. Blood pressure was corrected or improved in $81 \%$ one year after operation, the operative mortality (up to 30 days) being $7 \%$. Several reviews of the American literature made in conjunction with the reports of personal series (Kaufman, 1965 ; Maxwell, 1966 ; Genest et al., 1966) show that in approximately 1,000 patients correction rates varied from 37 to $66 \%$, improvement rates from 16 to $45 \%$, correction plus improvement rates from 65 to $95 \%$, and mortality rates from 0 to $18 \%$.

Precise comparison of results between different centres is difficult, but these American overall results are similar to our own, where blood pressure was corrected or improved in $85 \%$ of patients. It is our view that if good results are to be attained, and moreover improved on, then both a satisfactory selection of patients for surgery and expert vascular surgery are required, and these can be obtained only by experienced medical and surgical teams working in close co-operation.

\section{Case Selection}

Renal artery stenosis possibly suitable for renovascular surgery is uncommon, probably representing only 3 to $5 \%$ of the hypertensive population (Kennedy et al., 1965). It can mimic all degrees of severity of "essential" hypertension and can occur in all age groups. Clinical features which may be of value in diagnosis are a renal bruit and recent onset or abrupt change in the character or rapid progression of hypertension, but these are seldom decisive. We have been impressed by the relative frequency of a history of hypertension dating back to a toxaemia of pregnancy or of a history of recurrent toxaemia of pregnancy in young females with renovascular hypertension. Polycythaemia is a rare association with renovascular hypertension due to renal artery stenosis (Luke et al., 1965). In this series the length of history or duration of hypertension, where known, was relatively short at 13 months. Maxwell (1966) found a significantly longer duration of hypertension in those failing to respond than in those responding to renovascular surgery ; but contrary views are expressed by Owen (1967), and in our experience the presence of hypertension for a considerable period, especially in a young patient, by no means precludes correction of hypertension by surgery, as, for example, in Case 25, where hypertension was known to have been present for 12 years.

A safe, reasonably practical, and yet reliable screening procedure for renovascular hypertension is clearly mandatory (Lancet, 1966 ; Brit med. f., 1967) so that the more elaborate and potentially harmful investigations are confined to a small selected group. We continue to hold the view that the combination of the I.V.P. and the renogram offers such a screening process, though we believe that the screening procedure may be improved in the future by the addition of a humoral assay on peripheral blood. 
It is important to decide at the outset whether the patient's hypertension is significant enough to merit investigation and whether a surgical approach would be feasible. Some patients are sensibly excluded from even the initial screening procedure by their age, relative insignificance of the hypertension, or the presence of coincidental disease such as severe atherosclerosis of the brain, heart, or peripheral vessels, severe chronic respiratory disease, or because of significantly impaired renal function. Though Morris et al. (1966) and Gifford and Poutasse (1965) claim that azotaemia itself may offer an indication for operation in renal artery stenosis with renal atrophy, we believe that a search for renovascular hypertension is unlikely to be justified if the blood urea is above $70 \mathrm{mg} . / 100 \mathrm{ml}$. and the creatinine clearance below about $45 \mathrm{ml} . /$ minute, especially where the patient does not have accelerated hypertension. In malignant hypertension, where some of the renal impairment may be due to potentially remediable acute hypertensive vascular changes, it is perhaps more justifiable to attempt renovascular surgery at the lower limits of these values. Thus in Case 22 malignant hypertension, poorly controlled by drugs, was dramatically corrected (B.P. 120/80) by removal of a contracted kidney $(60$ g.).

\section{Preoperative Tests}

When screening tests suggest functionally significant renal artery stenosis there is disagreement over which further tests are required in order to allow a decision on surgical intervention. An aortogram is essential in order to demonstrate the anatomical relations of the lesion to the surgeon. No matter which plan of investigation is used there is now wide agreement that merely anatomical renal artery stenosis (Eyler et al., 1962 ; Holley et al., 1964) is not an indication for surgery aimed at correcting hypertension. Though the exact pathogenesis of renovascular hypertension is not yet known there is certainly a close relation between the alteration in renal plasma flow, glomerular filtration rate, and tubular sodium and water reabsorption distal to functional stenosis and hypertension (Stamey, 1966).

Some authors (Stamey, 1965 ; Peart, 1966) insist on divided renal function tests as a routine before operation, but we believe that divided renal function tests are not essential provided the clinical features, I.V.P., renogram, and aortogram are all in agreement, since the I.V.P. and renogram are altered by functional renal artery stenosis for the same reasons as are divided renal function tests (Luke et al., 1966). Similarly, if the preoperative assessment is of clear-cut functional unilateral renal artery stenosis then we and others (Gifford and Poutasse, 1965) do not believe that demonstration of a definite transstenotic gradient is essential ; pressure measurements may sometimes be difficult to obtain for technical reasons, and, moreover, the results may be affected by a fall in blood pressure under anaesthesia. Nevertheless, pressure gradients should be measured during operation wherever possible, both before and after revascularization.

Biopsy of the ipsilateral kidney to study the juxtaglomerular apparatus and the arterioles, and of the contralateral kidney for small vessel changes, have been advocated, and Vertes et al. (1965) claimed that vascular changes in the contralateral kidney would prevent a response to operation. We have not done preoperative renal biopsies and believe that contralateral kidney biopsy could be hazardous, as that kidney is a potentially solitary one if surgery is performed. There is increasing evidence that the changes in the juxtaglomerular apparatus are not more helpful than other tests in deciding on operation, and that it is impossible to prognosticate from percutaneous renal biopsy whether changes in the contralateral kidney will preclude a response to surgery (Stamey, 1965; Kincaid-Smith, 1966 ; Owen, 1967 ; Maxwell et al., 1967). Stamey (1965) believes that measurement of renal plasma flow in the contralateral kidney is of value when deciding on surgery, cases with paraaminohippuric acid clearance rates of less than $200 \mathrm{ml} . / \mathrm{min}$. being unlikely to respond to operation. Our policy has been not to recommend operation unless the renogram and I.V.P. and nephrogram phase of aortogram on the contralateral kidney were normal, except occasionally in the case of malignant or accelerated hypertension as noted above. Stamey (1965) also recognizes this latter possibility of response to surgery despite lower plasma flow values in the contralateral kidney where malignant hypertension is present.

If the renin angiotensin mechanism is important in the pathogenesis of renovascular hypertension, assay of renin levels either in the peripheral blood or in the renal vein should, in theory at least, be valuable in deciding on surgery ; and indeed this view has been expressed, based on retrospective studies (Genest et al., 1966). However, other workers have found a scatter of values between essential and renovascular hypertension (Brown et al., 1966 ; Creditor and Loschky, 1967), and renin values are often high in malignant hypertension due to any cause (Brown et al., 1966). Peart (1966) goes no further than to state that "a patient with a low renin value is unlikely to have renovascular hypertension." The dramatic fall in blood pressure after operation in some patients (as in Case 22) is suggestive of a humoral mechanism. The mean rise in plasma sodium in our patients after surgery is of interest, in view of the reciprocal relation between plasma sodium and renin (Brown et al., 1965). However, the plasma sodium level would not have proved useful in deciding on surgery in any individual patient. Studies of renin levels in renovascular patients submitted to surgery should certainly continue.

Our own preoperative investigation consisting of I.V.P., renogram, and aortogram, with divided renal function tests only in some cases, is a relatively simple one, but the blood pressure response to surgery seen in 25 out of 26 patients suggests that it is reasonably adequate, at the present stage of our knowledge, for the selection of patients for surgery.

\section{Nature of Surgery}

There is no evidence that reconstructive vascular surgery is more likely to be associated with a good blood-pressure response than nephrectomy (Maxwell, 1966), but we would agree with Peart (1966) that every effort should be made to conserve functioning renal tissue and that reconstructive vascular surgery should be carried out wherever possible; and there is no doubt that increasing experience leads to a greater percentage of successful reconstructions. Reconstructive procedures, however, are often of necessity protracted, and, especially in the older patient, may carry a significant morbidity and mortality. We believe that in some patients nephrectomy may be the only step consistent with a reasonable risk. Furthermore, reconstructive surgery is not possible in a significant proportion of patients with fibromuscular dysplasia because of involvement of the distal renal artery by the disease process (Fenton et al., 1966 ; Hunt et al., 1967). Again, where the kidney on the stenotic side is small and shrunken it is unlikely that reconstructive vascular surgery will correct hypertension, probably because of the severe histological changes on that side (Kaufman, 1965; Maxwell et al., 1967). We have found the pattern of renogram curve over the affected kidney of value in making the choice between nephrectomy and reconstructive vascular surgery.

\section{Drug Therapy}

Drug therapy offers an obvious alternative to surgery in renovascular hypertension (Sheps et al., 1965 ; Dustan et al., 1966). There is a potential hazard that blood-pressure reduction by hypotensive drugs might precipitate vascular occlusion on the affected side, but this does not seem to have been an 
undue problem (Dustan et al., 1966), though some cases have been reported (Sheps et al., 1965 ; Gifford and Poutasse, 1965 ; Owen, 1967). Valid comparisons between the results of treatment in medically and surgically treated cases are not so far available, mainly because medical treatment in the reported series was being given to renovascular patients selected because they were older, had bilateral renal vascular lesions, had extenstve vascular disease, or were less fully studied than the operated cases (Dunstan et al., 1966 ; Owen, 1967). Fourteen of our patients with renal artery stenosis were not operated on for such reasons.

It is our view that where renovascular investigations reveal - functional unilateral renal artery stenosis with well-maintained function in the opposite kidney, surgery by an experienced group should in general be offered as the treatment of choice to the young patient with significant hypertension and to the Jlder patient with accelerated hypertension and in whom operation does not constitute an undue hazard. Where bilateral functional stenosis is present, as in Case 17, surgery is difficult and drugs are the first line of approach, but the otherwise gloomy prognosis if drugs fail to control the blood pressure may necessitate an attempt at bilateral revascularization.

\section{Conclusions}

As a result of our experiences in the detection of renovascular hypertension and the selection of such cases for surgery, we suggest the following policy.

(1) Assess the significance of the hypertension, total renal function, and fitness for possible surgery.

(2) In suitable cases proceed to I.V.P. and renogram.

(3) If the I.V.P. and renogram suggest unilateral renal artery stencels with renal ischaemia, if the opposite kidney is normal, and $\mathbb{H}$ the patient is young with significant hypertension or has eccelerated hypertension, proceed to aortography. If the clinical ieatures and tests are in agreement, and if there is no contraindleation, renovascular surgery is indicated ; if there is unsertafaty, divided renal function tests may also be required before the decision about surgery.

(4) In the older patient with less severe hypertension a trial sf drugs should be carried out even if renal artery stenosis is suspected on screening tests (I.V.P. and renogram). If the bloed pressure is poorly controlled or the side-effects of drugs are inolerable, or if hypertension becomes accelerated, :econsider a surgical approach.

(5) Reconstructive vascular surgery is preferred where feaslble, but nephrectomy is likely to be the operation of choice if the kidney is small, if the longer operation means an undue fisk, or if the distal renal artery is diseased.

(6) Postoperative isotope renograms provide a useful guide to the function of a reconstructed renal artery.

\section{Summary}

Renovascular surgery has been carried out in 27 patients with functionally significant renal artery stenosis. These 27 originated from a group of 41 patients with functional renal srtery stenosis found by studying approximately 1,000 hypertensive patients. Reconstructive vascular surgery was performed in 10 and nephrectomy in 17 patients. There was one immediate postoperative death, and two late deaths occurred at four and six months for reasons related to reconstructive surgery ; in both of these cases the blood pressure was corrected between surgery and death. Of the remaining 24 patients assessed at least one year after surgery, with a mean assessment time of 25 months, the blood pressure was corrected (less than
$90 \mathrm{~mm}$. $\mathrm{Hg}$ diastolic) in 16 and improved (fall of diastolic by at least $20 \mathrm{~mm}$. $\mathrm{Hg}$ without hypotensive drugs; mean fall $27 \mathrm{~mm} . \mathrm{Hg}$ ) in seven.

It is suggested that the I.V.P. and renogram offer a suitable screening procedure for hypertensive patients, that aortography is necessary before surgery in all cases, but that differential renal function tests are not necessarily required before surgery.

In the older patient with less severe hypertension, even if the screening tests suggest renal artery stenosis, drugs should be given a trial before proceeding to more complicated tests.

Reconstructive vascular surgery should be aimed at wherever possible, but nephrectomy is more appropriate in those unfit for a prolonged operation or with a contracted ipsilateral kidney or with distal disease of the affected renal artery.

Many of the patients in this series were referred to us by mem bers of the Hypertension Unit, Department of Cardiology, by the physicians in Glasgow Royal Infirmary, and by physicians in other hospitals in Glasgow and the West of Scotland ; we are grateful to them for their co-operation. We would also like to thank Professor W. A. Mackey, Department of Surgery, Royal Infirmary, who, with Mr. D. W. Short, operated on two patients (Cases 4 and 17); Dr. W. P. Duguid, of the Department of Pathology, Royal Infirmary and those radiologists who carried out some of the investigations before referral.

\section{REPERENCES}

Brit. med. J., 1967, $2,4$.

Brown, J. J., Davies, B. L., Lever, A. F., and Robertson, J. I. S. (1965) Brit. med. \%., 2, 144.

Brown, J. J., Lever, A. F., Davies, D. L., and Robertson, J. I. S. (1966) Postgrad. med. F., 42, 153.

Brown, J. J., Owen, K., Peart, W. S., Robertson, J. I. S., and Sutton, D. (1960), Brit. med. \%., 2, 327.

Chamberlain, M. J., and Gleeson, J. A. (1965). Lancet, 1, 619.

Creditor, M. C., and Loschky, U. K. (1967). Amer. Y. Med., 43, 371.

Dustan, H. P., Meaney, T. F., and Page, I. H. (1966). In Antihypertensive Therapy, edited by F. Gross, p. 544. Berlin.

Byler, W. R., Clark, M. D., Garman, J. E., Rian, R. L., and Meininger, D. B. (1962). Radiology, 78, 879.

Fenton, S. S. A., Lyttle, J. A., and Pantridge, J. F. (1966). Lancet, 2, 117.

Genest, J., et al. (1966). In Antihypertensive Therapy, edited by F. Gross. p. 518. Berlin.

Cafford, R. W., and Poutasse, E. F. (1965). Progr. cardiovasc. Dis., 8,

Groden, B. M., James, W. B., and Davidson, J. K. (1966). Postgrad. med. F., 42, 177 .

Farrison, E. G., Hunt, J. C., and Bernatz, P. E. (1967). Amer. F. Med.

Holley, K. E., Hunt, J. C., Brown, A. L., jun., Kincaid, O. W., and Sheps, S. G. (1964). Amer. F. Med., 37, 14.

Hunt, J. C., Bernatz, P. E., and Harrison, E. G. (1967). Circulat. Res., Suppl. No. 2, vol. 21, p. 211.

Kaufman, J. J. (1965). F. Urol., 94, 211.

Keith, N. M., Wagener, H. P., and Barker, N. W. (1939). Amer. Y. med. Sci., 197, 332.

Kennedy, A. C., Luke, R. G., Briggs, J. D., and Stirling, W. B. (1965)


Gross, p. 485. Berlin.

Lancet, 1966, $2,94$.

Luke, R. G., Brigys, J. D., Kennedy, A. C., and Stirling, W. B. (1966) Quart. F. Med., 35, 237.

Luke, R. G., Kennedy, A. C, Stirling, W. B., and McDonald, G. A (1965). Brit. med.' Y., 1, 164.

Merwell, M. H. (1966). Proc. 3rd Int. Congr. Nephrol., 3, 131.

Marwell, M. H., Lupu, A. N., and Franklin, S. S. (1967). Circulat. Res.,

Suppl. No. 2, vol. 21, P. 201. Zauger, I. C. C. (1966). Surg. Gynec. Obstet., 122, 1255.

Owen, K. (1967). XIV Kongress der internationalen Gesellschaft for

Paroons, V., Cameron, J. S., and Gray, B. (1965). Guy's Hosp. Rep.. 114, 114 .

Peart, $W$. S. (1966). In Antihypertensive Therapy, edited by F. Groes.

Sheps, S6. G., Osmundson, P. G., Hunt, J. C., Schirger, A., and Fairbairm

J. .̦. G., Osmundson, P. G., Hunt, J. C., Schirs). Clin. Pharmacol. Ther., 6, 700 .

Short, D. W., Kennedy, A. C., Luke, R. G., and Mackey, W. A. (1965) Brit. Y. Surg. 52, 963.

Stamey, T. A. (1965). Amer. Y. Med., 38, 829.

Stamey, T. A. (1966). In Antihypertensive Therapy, edited by F. Gross. p. 555 . Berlin. 272, 186.
Prauel, J. A., and Goldblatt, H. (1965). New Engl. \}. Med., 